\title{
Failure of Direct-Acting Antiviral Agents Due to Incomplete Hepatitis C Virus Genotyping
}

\author{
Eksik Hepatit C Virüs Genotip Tayini Nedeniyle Direkt Etkili Antiviral Tedavi Bașarısızlığı
}

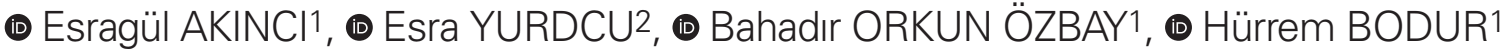 \\ 1 University of Health Sciences, Ankara Numune Training and Research Hospital, Clinic of Infectious Diseases and Clinical Microbiology, Ankara, Turkey \\ ${ }^{2}$ Ankara University Faculty of Medicine, Department of Hepatology, Ankara, Turkey
}

\begin{abstract}
Current direct-acting antivirals (DAAs) have high success rates in the treatment of chronic hepatitis $\mathrm{C}$ virus $(\mathrm{HCV})$ infection. However, $1-15 \%$ of patients fail to achieve viral eradication. Some factors may play a role in the treatment failure and relapse. In this paper, we present two cases of hepatitis $C$ in which DAAs failed due to incomplete HCV genotyping.

Keywords: Chronic hepatitis C, direct-acting antivirals, hepatitis C virus
\end{abstract}

\section{ÖZ}

Günümüzde direkt-etkili antiviral (DEA) ilaçlar ile kronik hepatit $C$ virüs tedavisinde yüksek başarı oranlarına ulaşılmıştır. Bununla birlikte \%1-15 hastada viral eradikasyon sağlanamamaktadır. Bazı faktörler tedavi başarısızlığında ve relapslarda rol oynayabilir. Bu olgu sunumunda, eksik genotip tayini nedeniyle tedavide başarısız olunan iki olgu sunulmuştur.

Anahtar Kelimeler: Kronik hepatit C, direkt etkili antiviraller, hepatit $C$ virüs

Akıncı E, Yurdcu E, Orkun Özbay B, Bodur H. Failure of Direct-Acting Antiviral Agents Due to Incomplete Hepatitis C Virus Genotyping. Viral Hepat J. 2018;24:96-98.

\section{Introduction}

Current direct-acting antivirals (DAAs) have high success rates in the treatment of chronic hepatitis $\mathrm{C}$ virus (HCV) infection. Despite important advances in HCV clearance by DAA therapies, about $1-15 \%$ of patients fail to achieve virological eradication (1). Some factors may play a role in treatment failure and relapse. These factors are difficult-to-treat genotypes, advanced fibrosis, suboptimal treatment regiments, poor compliance of patients, drugdrug interactions, drug resistance, and inaccurate or incomplete genotyping $(1,2)$. Genotyping errors, such as indeterminate results, incomplete genotyping in mixed genotype infections, wrong genotyping or subtyping may cause treatment failure in up to $10 \%$ of cases (1). In this paper, two cases of chronic hepatitis $\mathrm{C}$ in which DAAs failed due to incomplete HCV genotyping are presented.

Patients permitted their data for publication.

\section{Cases}

\section{Case 1}

A 39-year-old male patient was admitted to the hospital with the diagnosis of genotype $1 \mathrm{~b}$ chronic hepatitis $\mathrm{C}$ infection in November 2017. He had no risk factor for transmission of HCV such as blood transfusion or intravenous (IV) drug abuse. His HCV RNA level was $3310000 \mathrm{IU} / \mathrm{mL}$, alanine aminotransferase (ALT) was $95 \mathrm{U} / \mathrm{L}$ and aspartate aminotransferase (AST) was $50 \mathrm{U} / \mathrm{L}$. The liver biopsy revealed fibrosis $3 / 6$ and histology activity index (HAl) 10/18. He was treatment-naive and ombitasvir/paritaprevir/ritonavir + dasabuvir was started for 12 weeks. At follow up, HCV RNA was negative in the second month of therapy. However, one month after completion of the therapy, HCV RNA [real time-polymerase chain reaction RT-PCR)] was found to be positive (22600000 IU/ $\mathrm{mL}$ ) and ALT and AST levels were elevated (281 U/L and $92 \mathrm{U} / \mathrm{L}$, 
respectively). At follow up, increased liver enzymes on liver function test continued. One month later, ALT and AST levels reached to 467 $U / L$ and $197 \mathrm{U} / \mathrm{L}$, respectively. Prothrombin time (PT), international normalized ratio (INR), thrombocyte, albumin and biluribin levels were within the normal ranges. Other hepatitis serology (hepatitis $A$ and $B$ ) and autoimmune markers were negative. His physical examination was normal. He had no complaints and no risk of exposure to $\mathrm{HCV}$ in the last 6 months. Relapse was thought and genotype testing was repeated by sequencing analysis. NS5B and $5^{\prime} U T R$ region of $\mathrm{HCV}$ genome were analyzed ( $\mathrm{ABI}$, BigDye Terminator v3.1 Cycle Sequencing Kit). At this time, genotype 3a was detected. Because, there was no risk of exposure to $\mathrm{HCV}$, re-infection was excluded. Mixed genotype infection ( $1 b+3 a)$ was thought with higher probability. The patient was followed weekly. After 3 months, his ALT and AST levels decreased to the normal levels but HCV RNA persisted positive $(54300 \mathrm{IU} / \mathrm{mL})$.

\section{Case 2}

A 23-year-old male patient was admitted to the hospital with the diagnosis of genotype $1 \mathrm{~b}$ chronic hepatitis $\mathrm{C}$ infection in December 2017. He had a history of IV drug abuse, but he gave up two years ago. His HCV RNA level was $841000 \mathrm{IU} / \mathrm{mL}$ (RT-PCR), ALT: $86 \mathrm{U} / \mathrm{L}$ and AST: $35 \mathrm{U} / \mathrm{L}$. Liver biopsy revealed fibrosis stage of 2/6 and HAl score of 7/18. He was treatment-naive and ombitasvir/paritaprevir/ritonavir + dasabuvir was started for 12 weeks. At follow up, HCV RNA levels were negative at the first and second months of therapy. However, at the end of therapy, HCV RNA was found to be positive $(7240 \mathrm{lU} / \mathrm{mL})$ and the level of ALT was elevated (60 U/L). Increased liver enzymes on liver function test and rise of HCV-RNA continued. A month later, the level of ALT was $305 \mathrm{U} / \mathrm{L}$, AST was $97 \mathrm{U} / \mathrm{L}$ and HCV-RNA was 392000 $\mathrm{IU} / \mathrm{mL}$. PT, INR, thrombocyte, albumin and bilirubin levels were within the normal ranges. Other hepatitis serology (hepatitis B and A) and autoimmune markers were negative. He had no clinical symptoms and his physical examination was completely normal. His genotyping test was repeated by sequencing analysis. NS5B and 5'UTR region of HCV genome were analyzed (ABI, BigDye Terminator v3.1 Cycle Sequencing Kit) and genotype 2b was detected. He had no risk of exposure to HCV and IV drug abuse in the last 2 years, thus, re-infection was excluded. Mixed genotype infection $(1 b+2 b)$ was thought and he was followed weekly. After 3 months, his ALT and AST levels were within the normal ranges, but HCV RNA was still positive (45100 IU/mL).

\section{Discussion}

We have a small amount of real-life data on DAA failure in patients with chronic hepatitis $C$. In a recent study, characteristics of 87 patients with failure to interferon-free regimens were reported (3). Of these 87 patients, misclassified HCV genotype was detected in 13 (14.9\%), 16 patients (18.4\%) were treated with sub-optimal DAA regimen and 19 (21.8\%) received simeprevirbased regimen. Nearly half of the patients $(39,44.8 \%)$ were treated with an optimal DAA regimen. In the 10 of 13 misclassified genotypes, genotype 3 was the wrongly detected genotype and these patients were treated with an ineffective DAA regiments. The authors emphasized that especially misidentification of genotype 3 by commercial assays may cause a trouble in clinical practice and underlined the need for accurate detection of the HCV genotype in order to prevent ineffective treatment. HCV genotyping by more recent methods or by sequencing may warrant the identification of correct genotypes or subtypes.

The efficacy of DAAs varies according to the HCV genotype. Thus, treatment regimen is tailored to the genotype of the virus. So that, accurate diagnosis of mixed genotype infections is needed for the success of treatment. The prevalence of mixed genotype $\mathrm{HCV}$ infections varies between studies depending on the study design, patient populations and genotype detection methods. In a study performed in the United Kingdom (UK), it was observed that infection by more than one HCV found in $9 \%$ of 44 injecting drug users and in 19\% of 37 patients with bleeding disorders (4). In another recently published study from the UK, sera samples of 506 individuals diagnosed with either genotypes of $1 \mathrm{a}$ or 3 infection were re-screened for mixed infections by genotypespecific PCR and deep sequencing (5). The total rate of mixed genotype infection was found to be $3.8 \%$. As $6.7 \%$ of samples diagnosed with genotype 3 were harboring genotype $1 a, 0.8 \%$ of samples diagnosed with genotype 1a were harboring genotype 3 $(p<0.05)$. Mixed genotype infection samples included major and minor genotypes. Minor genotype constituted less than $21 \%$ of the total viral load and less than $1 \%$ of the viral load in $67 \%$ of cases. A study form Turkey also suggested being careful with mixed genotype HCV infections. In this study, 21 of 495 (4.2\%) patients with chronic hepatitis $\mathrm{C}$ had mixed genotype infections and of them, 15 (71\%) were IV drug users (6). Genotype 1b-4 (7 patients) and genotype 2-3 (6 patients) were the most frequent mixed genotypes.

In this case report, coincidentally, these two patients were admitted to the hospital consecutively and HCV RNA reversed to positive at the end of therapy. There was no risk of exposure in the last 6 months. In both of them, repeated HCV RNA tests revealed different genotypes from the first ones. In the first genotyping tests, the RT-PCR (Rotor Gene Real Time PCR, Qiagen) method was used. In the second genotyping tests, a more sensitive and more specific test, sequencing analysis, was preferred. The NS5B and $5^{\prime} U T R$ regions of the HVC genome were amplified by PCR. Amplified PCR products were sequenced directly and different genotypes were detected. In these patients, the first genotype (1b) was accepted as the major genotype with higher viral loads and the second genotypes ( $3 a$ and $2 b$ ) were as minor genotypes with lower viral loads. After treatment with ombitasvir/paritaprevir/ ritonavir + dasabuvir, which is effective in major genotype (1b), HCV RNA became negative. However, as a result of activation of minor genotypes $(3 a, 2 b)$, which are out of the spectrum of the antiviral therapy, HCV RNA reversed to positive and liver enzymes were elevated again.

Resistance-associated substitutions (RASs) may play a role in treatment failure of DAA therapy. In patients with virologic breakthrough, RASs are mostly observed. In addition, RASs are detected between 53\%-91\% in patients with virologic relapse (1). However, clinical impact of RASs is much more limited $(1,2,7)$. Currently, clinically, the most important RASs are in the NS5A position for genotypes 1a and 3 (8). In our two cases, resistance associated mutation was not detected. 
In conclusion, these cases indicated that mixed genotype HCV infections should be kept in mind especially in IV drug users and haemophiliacs. The HCV population structure involved a major and a minor genotype in mixed genotype infections. Thus, low viral load of minor genotype may not be detected by less sensitive and less specific PCR techniques. So that, especially in patients with risk of mixed genotype HCV infections, more effective genotyping methods should be preferred. If it is not possible, pangenotypic DAAs may be chosen.

\section{Ethics}

Informed Consent: Patients permitted their data for publication. Peer-review: Externally peer-reviewed.

\section{Authorship Contributions}

Medical Practices: E.A., B.O.Ö., Design: E.A., Data Collection or Processing: E.A., B.O.Ö., Analysis or Interpretation: E.Y., E.A., Literature Search: E.A., Writing: E.A., B.O.Ö., H.B.

Conflict of Interest: No conflict of interest was declared by the authors.

Financial Disclosure: The authors declared that this study received no financial support.

\section{References}

1. Bagaglio S, Uberti-Foppa C, Morsica G. Resistance Mechanisms in Hepatitis C Virus: implications for Direct-Acting Antiviral Use. Drugs. 2017;77:1043-1055.
2. Wyles DL, Luetkemeyer AF. Understanding Hepatitis C Virus Drug Resistance: Clinical Implications for Current and Future Regimens. Top Antivir Med. 2017;25:103-109.

3. Starace M, Minichini C, De Pascalis S, Macera M, Occhiello L, Messina V, Sangiovanni V, Adinolfi LE, Claar E, Precone D, Stornaiuolo G, Stanzione M, Ascione T, Caroprese M, Zampino R, Parrilli G, Gentile I, Brancaccio G, lovinella V, Martini S, Masarone M, Fontanella L, Masiello A, Sagnelli E, Punzi R, Salomone Megna A, Santoro R, Gaeta GB, Coppola N. Virological patterns of HCV patients with failure to interferon-free regimens. J Med Virol. 2018;90:942-950

4. Buckton AJ, Ngui SL, Arnold C, Boast K, Kovacs J, Klapper PE, Patel B, Ibrahim I, Rangarajan S, Ramsay ME, Teo CG. Multitypic hepatitis $C$ virus infection identified by real-time nucleotide sequencing of minority genotypes. J Clin Microbiol. 2006;44:2779-2784

5. McNaughton AL, Sreenu VB, Wilkie G, Gunson R, Templeton $\mathrm{K}$, Leitch ECM. Prevalence of mixed genotype hepatitis $C$ virus infections in the UK as determined by genotype specific PCR and deep sequencing. J Viral Hepat. 2018;25:524-534.

6. Mutay SB, Unal N. Miks genotip ile enfekte kronik hepatit C hastalarında DAA tedavi deneyimimiz ve miks genotip prevalansımız. XIV. Ulusal Viral Hepatit Kongresi, 26-29 Nisan 2018, Antalya, SS-04-17.

7. David L. Wyles. Resistance to DAAs: When to Look and When It Matters. Curr HIV/AIDS Rep. 2017;14:229-237.

8. HCV Guidance: Recommendations for Testing, Managing, and Treating Hepatitis C. AASLd and IDSA Guideline, https://www. hcvguidelines.org/ (27.09.2018) 